Original Research Paper

\title{
Value-Added Analysis of Duck Meat Supply Chain in Malang, Indonesia
}

\author{
*Nanang Febrianto, Budi Hartono and Alditya Putri Yulinarsari \\ Faculty of Animal Science, Universitas Brawijaya, Malang, Indonesia
}

\author{
Article history \\ Received: 15-03-2021 \\ Revised: 24-05-2021 \\ Accepted: 26-06-2021 \\ Corresponding Author: \\ Nanang Febrianto \\ Faculty of Animal Science, \\ Universitas Brawijaya, Malang, \\ Indonesia \\ Email: nanangfeb@ub.ac.id
}

\begin{abstract}
This study aims to analyze the added value of the duck meat supply chain in Malang, Indonesia. The respondents in this study were duck farmers, distributors, suppliers, duck meat restaurants and consumers. The study was conducted through a survey with purposive and snowball sampling methods and then analyzed descriptively. The results showed that there were two distribution channels of the duck meat supply chain in Malang. The first distribution channel (Channel I) consisted of duck farmer, duck supplier in Blitar Regency, fried duck restaurant and consumers in Malang; while the second distribution channel (Channel II) consisted of duck farmer, distributor, duck supplier in Blitar Regency, fried duck restaurant and consumers in Malang. The results showed that the highest added value was found in Channel I, with $75.19 \%$ added value was obtained. The study concludes that Channel I had a better distribution channel of duck meat supply chain in Malang as indicated by the higher obtained added value.
\end{abstract}

Keywords: Distribution Channel, Duck Farming, Marketing, Profitability

\section{Introduction}

Duck farming for meat and egg production has a promising potential to be developed in Indonesia. The current duck farming practice is still done through the conventional farming method without any modern technological approach (Susanti et al., 2020; Basriwijaya et al., 2021). The duck meat production in Indonesia was about 36.4 thousand ton in 2017, while in 2020 increased to about 37.5 thousand ton (DGLAHS, 2020). While in Malang, duck meat production reached 15.9 ton in 2017 and increased to 26.1 ton in 2018 (CBSJT, 2019). The condition reflects the increasing demand for the product as well, with restaurants in Malang, Indonesia, have served fried duck as their main dish. Moreover, there are two types of consumers on the fried duck restaurants, the first type is consumers who come to dine in and the other would order the fried duck through an online-based application to order their food without the need to come to the restaurants.

The high demand for a fried duck food in Malang attracts duck meat suppliers even from duck farmers who raised their ducks outside of Malang. To improve the current condition, a good supply chain management of the duck meat is then become essential. A supply chain is a structured manufacturing process of raw materials into finished goods and delivered to the end-user/consumer. The supply chain would involve suppliers, manufacturers and retailers who directly or indirectly work together to fulfill the consumer's need. The supply chain would give added value to the product during the delivery process through the involved participants (Janvier-James, 2012).

The supply chain mechanism of agricultural products in developing countries like Indonesia is characterized by weak products and weak market share. On the other hand, both the product and market would determine the sustainability of the supply chain, whether in a conventional or modern market chain. Marimin and Maghfiroh (2010) described that a conventional market chain started when farmers sell their products directly to the market or to brokers/distributors who will then sell the products in the traditional/modern market. In a study by Dawan and Darana (2018), there were three marketing channels of ducks meat, including: (a) Farmers as producers continue to collector traders, retailers and then to consumers, (b) farmers to wholesalers, retailers and then to consumers and (c) farmers continue to wholesalers, distributors, retailers and consumers.

In the supply chain system, the marketing of the product is done by involved participants who increase the value of the product or commonly known as added value. Sihombing and Sumarawu (2015) defined that added value as the increased value of a commodity due to whether processing, shipping, or even storing in its production process. In this study, we determine and analyze the valueadded of duck meat supply chain in Malang, Indonesia. The result of this study is hoped to provide information on the duck meat supply chain in Malang so that a robust business model or policy could be made for all involved stakeholders. 
Table 1: Value-added analysis (Hayami et al., 1987)

\begin{tabular}{|c|c|c|}
\hline Variable & Unit & Value supply chain \\
\hline \multicolumn{3}{|l|}{ Input, output and price } \\
\hline Output & Ducks/period & A \\
\hline Raw material & Ducks/period & B \\
\hline Direct labor & Person & $\mathrm{C}$ \\
\hline Conversion factor & & $\mathrm{D}=\mathrm{A} / \mathrm{B}$ \\
\hline Coefficient of direct labor & Person/duck & $\mathrm{E}=\mathrm{C} / \mathrm{B}$ \\
\hline Output price & $\mathrm{IDR}^{1} / \mathrm{duck}$ & $\mathrm{F}$ \\
\hline Labor wage & IDR/period ${ }^{2}$ & G \\
\hline \multicolumn{3}{|l|}{ Revenue and profit } \\
\hline Raw material price & IDR/period & $\mathrm{H}$ \\
\hline Other input prices & IDR/period & I \\
\hline Output value & IDR/period & $\mathrm{J}=\mathrm{A} \times \mathrm{F}$ \\
\hline Value-added & IDR/period & $\mathrm{K}=\mathrm{J}-\mathrm{H}$ \\
\hline Value-added ratio & $\%$ & $\mathrm{~L}=\mathrm{K} / \mathrm{J} \times 100$ \\
\hline Profit & IDR/period & $\mathrm{M}=\mathrm{J}-\mathrm{H}-\mathrm{I}-\mathrm{G}$ \\
\hline Profit rate & $\%$ & $\mathrm{~N}=\mathrm{O} / \mathrm{J} \times 100$ \\
\hline
\end{tabular}

${ }^{1} \mathrm{IDR}=$ Indonesian Rupiah, ${ }^{2}$ one rearing period equals to 40 days

\section{Materials and Methods}

The study was conducted in the established fried duck chain restaurant in Malang, Indonesia. The data was collected from duck farmers $(n=15)$, distributors $(n=3)$, suppliers $(n=7)$, restaurants $(n=1)$ and consumers $(n=$ 145 ) in December 2018. The duck farmers and restaurant were chosen through the purposive sampling method (Campbell et al., 2020), with the criteria as follow: (1) The restaurant should serve duck meat as the main dish; and (2) the duck farmers should have duck farming as their main source of income. The snowball sampling was done by following Drăgan and Isaic-Maniu (2012) to determine the involved participants in the duck meat supply chain, starting from the duck farmers to the restaurant in Malang. The snowball sampling showed that several duck farmers and duck meat suppliers are located in Blitar Regency, around $75 \mathrm{~km}$ and can be traveled in $2 \mathrm{~h}$ from Malang, while the distributors, restaurant and consumers are located in Malang. The value-added analysis was done by following Hayami et al. (1987), with the formulation as presented in Table 1.

\section{Results and Discussion}

The distribution channel flow of duck meat in Malang is presented in Fig. 1. It can be seen that the supply chain of duck meat in Malang is divided into two distribution channels. The first channel (Channel I) consisted of duck farmer; supplier; restaurant; and consumer, while the second channel (Channel II) consisted of duck farmer; distributor; supplier; restaurant; and consumer as the distribution participants. Moreover, the study also showed the occurrence of added value process by each participant. The added value is the change of product's value due to the processing by participants, such as additional processing or distribution during the supply chain. The supply chain analysis would determine the value-added and retribution of each participant. Xun and Cuixia (2012) explained that livestock-based products supply chain is different than other supply chains. The object of the livestock product supply chain is the livestock products and it coordinates the interest demand between the capital goods supplier of livestock products, farmers, livestock slaughtering and processing enterprises, livestock product brokers and consumers. The chain begins from the purchase of feed, veterinary medicine and livestock to finish a series of processes of the product production, processing and distribution. The livestock products supply chain is not only a production chain but also a value-added chain that increases its value during the process of processing, packaging and transportation of livestock products in the supply chain. In this study, the chain began from the farmer, who purchase the feed, medicine, breeding and raise the duck and end in the consumers who buy the fried duck dish as the final product.

The value chain approaches have been widely utilized to capture the interactions of complex markets in developing countries and to examine the inter-relationships between diverse actors involved in all stages of the distribution channel (Dolan and Humphrey, 2000; Kaplinsky, 2000; Schmitz and Knorringa, 2000; Giuliani et al., 2005; Bair and Peters, 2006; Pietrobelli and Saliola, 2008; Bolwig et al., 2010). Pica-Ciamarra (2005) described that the livestock chain systems are characterized by long marketing chains featuring great distances, numerous phases of weight gain and feeding regimes, many levels of traders and transactions, a multitude of steps and stages of processing and a variety of employmentcreating services and inputs. On the consumer side, the delivery of livestock products through informal markets tends to serve poor consumers, creating an even tighter focus on the poor and with potential multiplier effects for pro-poor development interventions. However, in this study, we found that the livestock chain system in duck products is relatively short, consisted of four to five distribution participants.

The supply chain of duck meat in Malang found in this study involves duck farmers as the producer, distributor who ship the duck to the supplier, supplier who slaughter and ship the meat duck to the restaurant and restaurant where the duck meat will be cooked for the end consumers. The chain is following the supply chain defined by Singh and Verma (2018) who stated that the supply chain is the flow from supplier to the customer through valueadded processes and distribution channels, which begins in the source of supply and ends at the end of consumption in an integrated structure model through the feedback information flow and feedback materials and information flow. In this study, each of the distribution participants has been involved in the value-added process which will be further discussed in the following section. Supply chain management would be required to secure the integrated process starting from the initial supplier to the end-users, 
whether for goods or services, in which its value will be added during each process (Lambert et al., 1998).

$\mathrm{Yu}$ and $\mathrm{Li}$ (2012) explained that there are some problems to be solved in the current livestock supply chain: The cost of transportation and herds, serious waste of the middle part, shortage of professional logistics talents, lack of financial support and no use of the concept of the total cost. In this study, we focused on the financial analysis of each distribution participant, while other factors such as produced waste and logistics are excluded. Fugate et al. (2006) further explained that the success of supply chain operations required high coordination of all participants in the whole chain and in turn, the implementation of supply chain management will affect the performance of all aspects. Moreover, Li et al. (2020) found that the computer database technology could be utilized to improve sales efficiency, targeted marketing design for products, avoid competition risk, reduce cost, provide accurate information to customers and then improve the whole society and economic benefits. In this study, the computer database technology were only utilized by the restaurants to distribute the product to the consumers through an online application. The utilization of computer database technology by other participants is then suggested to improve the overall supply chain management.

\section{Added Value at Duck Farmer}

Many of the development agencies have promoted poultry farming as a route out of poverty (McLeod et al., 2009), thus poultry farming is widely considered as a means to identify micro entrepreneurs. Khaleda (2013) explained that the poultry farmer activity in the value chain consisted of breeding, rearing and poultry raising. In this study, the main activity by the duck farmer is rearing and raising the duck. The duck farms in this study are located at Blitar Regency, East Java. The total reared duck population was varied from 1,000 to 1,750 ducks/period. The ducks were reared approximately for 40 days until weighed at 1.1 to $1.3 \mathrm{~kg}$ before sold to the supplier or distributor. The reared duck was Alabio and Mojosari crossbred, which served as dual purpose ducks (as egg and meat producer).

The laborers for duck farming were mainly from the farmer's family, while some farmers hired some laborers to support the duck rearing. The overview of duck farms in distribution channels I and II are presented in Fig. 2. The farmers sold their ducks through different distribution channels. It can be seen that the output price of the duck on Channel I was higher compared to Channel II (Table 2).

The output prices of the duck in Channel I and II were IDR 31,500 and IDR 25,000, respectively. The higher output price in Channel I is due to direct selling by the farmers to the supplier. Moreover, the labor input in Channel II is mostly from free labor and the conversion factor from the production input and output calculation in Channel I and II were 0.96 and 0.95 , respectively. The result showed that the ducks rearing had low mortality due to the intensive farming system. It was reported by Dawan and Darana (2017) that the intensive farming system resulted in the low mortality of the reared animals. Low mortality rates in the intensive production system is probably due to the proper management, diet and health programs. The obtained value-added at duck farmer in this study was IDR 36,384,000 with the ratio of $75.19 \%$ in Channel I and IDR 29,250,000 with the ratio of $68.42 \%$ in Channel II.

Fałkowski et al., (2017) mentioned that the farmers have always been in a weak position in the supply chain and are easy to be suffered due to the high transaction costs, cost of the contract and the relatively unstable feed price. However, a different result was shown in this study as duck farmers had the highest added value ratio compared to other participants (Table 2 - 5).

Table 2: Added value analysis at duck farmers

\begin{tabular}{|c|c|c|c|}
\hline \multirow[b]{2}{*}{ Variable } & \multirow[b]{2}{*}{ Unit } & \multicolumn{2}{|c|}{ Value supply chain } \\
\hline & & Channel I & Channel II \\
\hline \multicolumn{4}{|l|}{ Input, Output and Price } \\
\hline Output & Ducks/period & 1,536 & 1,663 \\
\hline Raw material & Ducks/period & 1,600 & 1,750 \\
\hline Direct labor & Person & 1.33 & - \\
\hline Conversion factor & & 0.96 & 0.95 \\
\hline Coefficient of direct labor & Person/duck & 0.001 & - \\
\hline Output price & $\mathrm{IDR}^{1} / \mathrm{duck}$ & 31,500 & 25,000 \\
\hline Labor wage & IDR/period $^{2}$ & $1,330,000$ & - \\
\hline \multicolumn{4}{|l|}{ Revenue and Profit } \\
\hline Raw material price & IDR/period & $12,000,000$ & $13,500,000$ \\
\hline Other input price & IDR/period & $20,631,000$ & $11,291,000$ \\
\hline Output value & IDR/period & $48,384,000$ & $42,750,000$ \\
\hline Added value & IDR/period & $36,384,000$ & $29,250,000$ \\
\hline Added value ratio & $\%$ & 75.19 & 68.42 \\
\hline Profit & IDR/period & $14,423,000$ & $17,959,000$ \\
\hline Profit ratio & $\%$ & 29.81 & 42 \\
\hline
\end{tabular}

${ }^{1}$ IDR = Indonesian Rupiah, ${ }^{2}$ one rearing period equals to 40 days 
Table 3: Added value analysis at the distributor

\begin{tabular}{lll}
\hline Variable & Unit & Value supply chain \\
\hline Input, output and price & Ducks/period & 6,000 \\
Output & Ducks/period & 6,000 \\
Raw material & Person & 2 \\
Direct labor & & 1.0 \\
Conversion factor & Person/duck & 0.003 \\
Coefficient of direct labor & IDR $1 /$ duck & 35,500 \\
Output price & IDR/period ${ }^{2}$ & $2,666,000$ \\
Labor wage & & $150,000,000$ \\
Revenue and profit & IDR/period & $3,608,000$ \\
Raw material price & IDR/period & $213,000,000$ \\
Other input price & IDR/period & $63,000,000$ \\
Output value & IDR/period & 29.58 \\
Added value & $\%$ & $56,726,000$ \\
Added value ratio & IDR/period & 26.63 \\
Profit & $\%$ &
\end{tabular}

${ }^{1}$ IDR = Indonesian Rupiah, ${ }^{2}$ one rearing period equals to 40 days

Table 4: Added value analysis at the supplier

\begin{tabular}{llll}
\hline & & Value supply chain & Channel II \\
Variable & Unit & Channel I & 2,120 \\
\hline Input, output and price & Ducks/period & 3,200 & 2,120 \\
Output & Ducks/period & 3,200 & 3 \\
Raw material & Person & 3 & 1.0 \\
Direct labor & & 1.0 & 0.01 \\
Conversion factor & Person/duck & 0.009 & 53,000 \\
Coefficient of direct labor & IDR $/$ duck & 53,000 & $3,999,000$ \\
Output price & IDR/period & $3,999,000$ & $213,000,000$ \\
Labor wage & & & $30,265,000$ \\
Revenue and profit & IDR/period & $100,800,000$ & $318,000,000$ \\
Raw material price & IDR/period & $17,474,000$ & $105,000,000$ \\
Other input price & IDR/period & $169,600,000$ & 33.01 \\
Output value & IDR/period & $68,800,000$ & $70,736,000$ \\
Value added & $\%$ & 40.57 & 22.25 \\
Value-added ratio & IDR/period & $47,327,000$ & 27.9 \\
Profit & $\%$ & & \\
Profit ratio & Ped &
\end{tabular}

${ }^{1} \mathrm{IDR}=$ Indonesian Rupiah, ${ }^{2}$ one rearing period equals to 40 days

Table 5: Value-added analysis at the fried duck restaurant

\begin{tabular}{llc}
\hline Variable & Unit & Value supply chain \\
\hline Input, output and price & Ducks/period & 9,200 \\
Output & Ducks/period & 9,200 \\
Raw material & Person & 8 \\
Direct labor & & 1.0 \\
Conversion factor & Person/duck & 0.007 \\
Coefficient of direct labor & IDR $1 /$ duck & 100,000 \\
Output price & IDR/period ${ }^{2}$ & $11,200,000$ \\
Labor wage & & $487,600,000$ \\
Revenue and profit & IDR/period & $565,348,000$ \\
Raw material price & IDR/period & $920,000,000$ \\
Other input price & IDR/period & $432,400,000$ \\
Output value & IDR/period & 47.00 \\
Value added & $\%$ & $144,148,000$ \\
Value-added ratio & IDR/period & 15.67 \\
Profit & $\%$ & \\
Profit ratio & &
\end{tabular}

${ }^{1} \mathrm{IDR}=$ Indonesian Rupiah, ${ }^{2}$ one rearing period equals to 40 days 


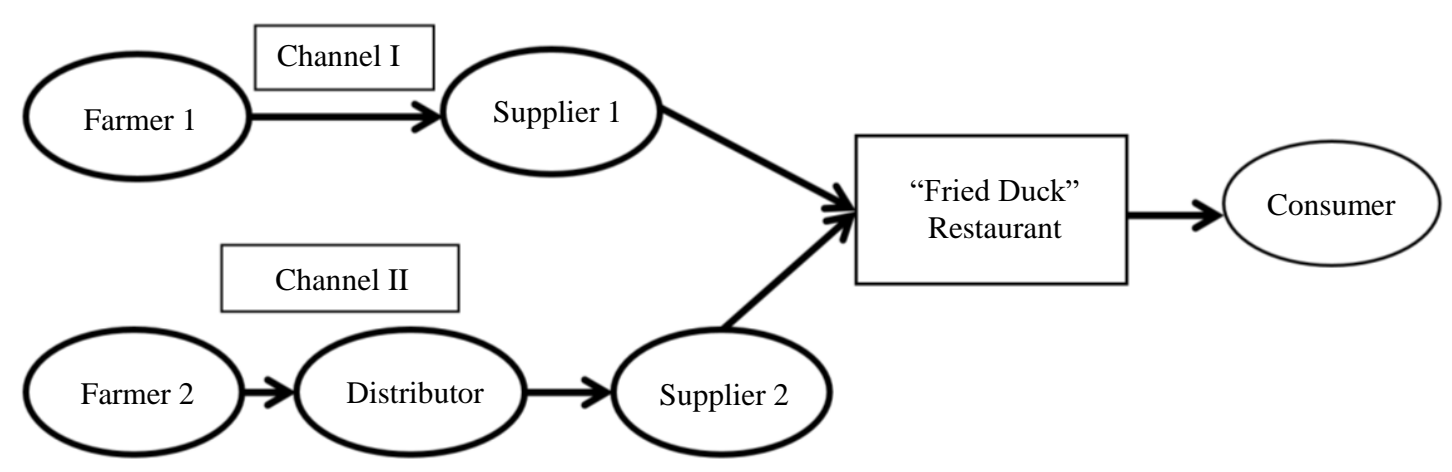

Fig. 1: Distribution channel of duck meat

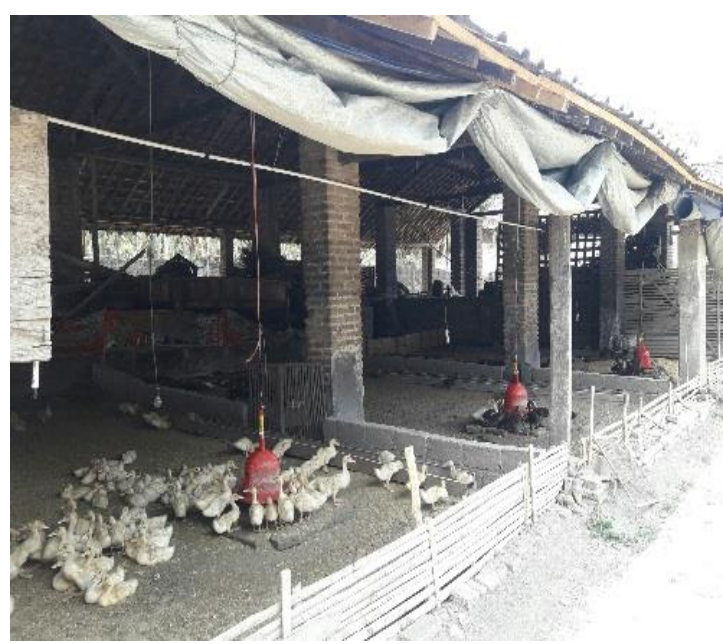

(a)

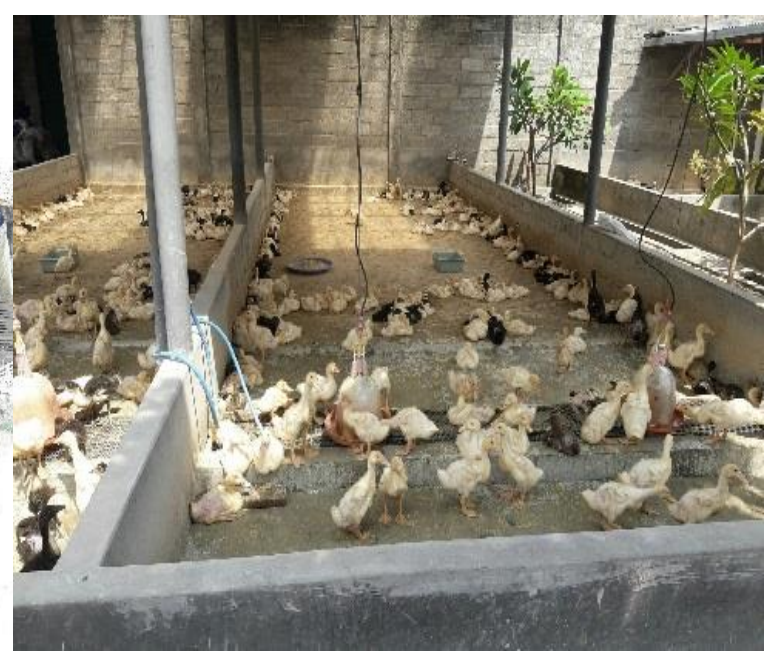

(b)

Fig. 2: The overview of duck farm in distribution Channel 1 (a) and Channel II (b)

This finding probably because most of the duck farmers are joined in the farmers' association so that they have good position in the supply chain. Moreover, the current result is probably also related to the relatively short supply chain of the duck meat, added with the condition that the farmers reared their ducks independently, so the transaction costs can be suppressed. Besides, the risk factors are excluded from this study, while in this supply chain farmers would suffer the highest risk due to the unstable price of farming materials (feeds, medicine, etc.) as well as the farming failure (sickness, low production, or high duck mortality).

\section{Added Value at Distributor}

The added value analysis at the distributor is presented in Table 3. The distributor in this study hired 2 labors to sell 6,000 ducks in 40 days (one period) to the supplier. The output at the distributor in this study was IDR $213,000 /$ period with the added value at IDR $63,000 /$ period at the ratio of $29.58 \%$. Moreover, the obtained added value was from the marketing activities by the distributor, before reduced with labor cost.

Magdelaine et al. (2008) described that the role of the distributor is to mark the products with quality signals, such as by giving commercial labels, official certifications, logos, etc. Those activities would then tackle problems faced during marketing the product to the consumers and provide consumers with product recognition. In this study, the only added value activity by the distributor is to deliver the ducks from farmers in Blitar Regency to the duck supplier in Malang. Although the activity resulted in a low added value ratio (Table 3 ), the activity has a low operating cost. Moreover, product recognition is still considered not important by the duck supplier.

\section{Added Value at Supplier}

Supplier is one of the main participants in the supply chain with relatively similar interest (Chopra and Meindl, 2007). The supplier is the first product provider from the producer to the next user in the 
supply chain. The product could be in the form of raw materials, additives, or finished products.

The supplier's activity in this study was processing the ducks into carcass for the fried duck restaurant. The processing includes slaughtering the ducks and remove the guts to produce carcass. Also, the duck guts were sold to the supplier. The carcass was cut into 4 parts and packaged before distributed to the fried duck restaurant daily.

The added value analysis at the supplier is presented in Table 4. In Channel I, every 3,200 carcass distribution required 3 laborers in a period with the output value at IDR $169,600,000$ and value-added at IDR 68,800,000 at the ratio of $40.47 \%$. In Channel II, every 3,120 carcass distribution required 3 laborers in a period with the output value at IDR 318,000,000 and value-added at IDR $105,800,000$ at the ratio of $33.01 \%$.

Manning et al. (2008) suggested that the development of suppliers requires the organizations involved to commit financial, capital and personnel resources to the development task and to share timely and sensitive information for performance improvement. Suppliers should focus on the consumer's demand, while also maintain product quality and continuity to ensure flexibility and quality of service with other members in the supply chain (Barratt, 2004; Manning and Baines, 2004). In this study, duck suppliers are obliged to provide duck meat to the restaurants. In this study, it is found that the duck suppliers' activity is focused on providing the duck meat suiting to the demands of the restaurant.

\section{Added Value at Fried Duck Restaurant}

The added value analysis in this study was done by measuring the obtained value-added in duck processing during distribution. The added value analysis in agricultural products can be done by measuring the increased value for each kilogram of the raw product after processing. Hayami et al. (1987) mentioned that the factors which affect value-added can be categorized as technical and market factor.

The fried duck restaurant in this study obtained the duck meat from suppliers and then processed the meat before distributing it to the consumer. The processing activities which give value added at the duck restaurant include separating and frying the duck parts and provide spicy tomato sauce to complete the dish for the consumer (Fig. 3). In Table 5, it can be seen that the restaurant could distribute as much as 9,200 duck/period, which required 8 labors in the process. Among the laborers, one of them works as administrators who works for $10 \mathrm{~h}$ /day for 7 days and paid as much as IDR 2,000,000/month. The other laborers were responsible to prepare the food and drink, serving the consumers, cleaning, packaging and managing the payment.

The value-added was analyzed by following the Hayami et al. (1987) method showed that the obtained conversion factor is 1.0 , which is calculated from the output and raw material during the distribution. The output value is calculated by multiplying the output price with the total output. The obtained output value in this study was IDR $920,000,000$ at the ratio of $47 \%$, thus the obtained added value was IDR 432,400,000. Moreover, the result of this study showed that value-added at the fried duck restaurant was higher compared to the duck farmer, distributor, or supplier. This indicates that the distribution activity at the fried duck restaurant was better compared to other activities by other distribution participants in the supply chain. The result of supply chain analysis in this study is different from the supply chain analysis of honey products by Qashiratuttarafi (2018), which showed that the highest value-added was obtained by packaging and distribution activity by the marketing outlet (supplier) with the added value ratio at $64 \%$.

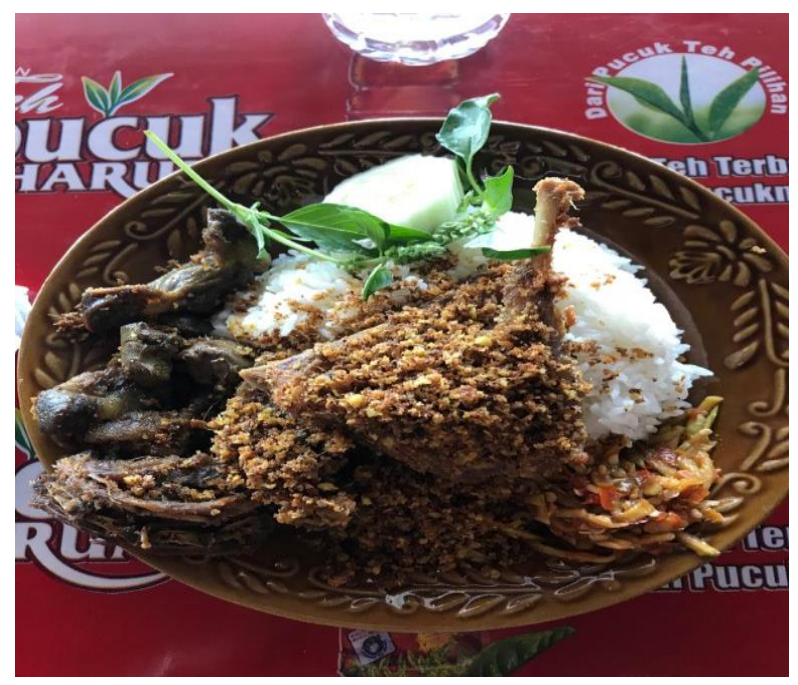

Fig. 3: Fried duck dish as the final product 


\section{Conclusion}

The study concludes that:

1. There were 2 distribution channels in the duck meat supply chain in Malang. Channel I started from the duck farmer and supplier at Blitar Regency, fried duck restaurant and consumers in Malang. On the other hand, Channel II started from the duck farmer, distributor and supplier at Blitar Regency, fried duck restaurant and consumers in Malang

2. The highest added value ratio was obtained by duck farmers in Channel I (75.19\%), while the highest profit ratio was obtained by duck farmers in Channel II (42\%) in the duck meat supply chain in Malang

3. Distribution Channel $\mathrm{I}$ is recommended in the duck meat supply due to the shorter chain and consequently lower price

\section{Acknowledgement}

We would like to thank Universitas Brawijaya for providing research funds in this study through the Universitas Brawijaya Research Professor Grants Program.

\section{Author's Contributions}

Nanang Febrianto and Alditya Putri Yulinarsari: Conception and design, data collection and analysis, drafting the article, and give final approval of the version to be submitted and any revised version.

Budi Hartono: Conception and design, data collection and analysis, reviewing article critically for significant intellectual content, and give final approval of the version to be submitted and any revised versión.

\section{Ethics}

The authors declare that there are no ethical issues may arise after the publication of this study.

\section{References}

Bair, J., \& Peters, E. D. (2006). Global commodity chains and endogenous growth: export dynamism and development in Mexico and Honduras. World Development, 34(2), 203-221. https://doi.org/10.1016/j.worlddev.2005.09.004

Barratt, M. (2004). Understanding the meaning of collaboration in the supply chain. Supply Chain Management: An International Journal. https://doi.org/10.1108/13598540410517566
Basriwijaya, K. M. Z., Sunarti, D., Ekowati, T., \& Sumekar, W. (2021, March). The Factors affecting Pitalah Duck farmer's income in Rokan Hulu district Riau province. In IOP Conference Series: Earth and Environmental Science (Vol. 672, No. 1, p. 012036). IOP Publishing. https://doi.org/10.1088/17551315/672/1/012036

Bolwig, S., Ponte, S., Du Toit, A., Riisgaard, L., \& Halberg, N. (2010). Integrating poverty and environmental concerns into value-chain analysis: a conceptual framework. Development policy review, 28(2), 173-194. https://doi.org/10.1111/j.14677679.2010.00480.x

Campbell, S., Greenwood, M., Prior, S., Shearer, T., Walkem, K., Young, S., Bywaters, D. and Walker, K., 2020. Purposive sampling: complex or simple? Research case examples. Journal of Research in Nursing, 25(8), 652-661. https://doi.org/10.1177\%2F1744987120927206

CBSJT. (2019). Meat Production by Regency/Municipality and Kind of Poultry in Jawa Timur Province, 2017-2018. https://jatim.bps.go.id/statictable/2019/10/09/1612/p roduksi-daging-unggas-menurut-kabupaten-kotadan-jenis-ternak-di-provinsi-jawa-timur-20172018.html

Chopra, S., \& Meindl, P. (2007). Supply chain management. Strategy, planning \& operation. In Das summa summarum des management (pp. 265-275). Gabler. https://link.springer.com/chapter/10.1007\%2F978-38349-9320-5_22

Dawan, T., \& Darana, S. (2017). Business profile of drake culture in West Java. Lucrări Științifice-Universitatea de Științe Agricole și Medicină Veterinară, Seria Zootehnie, 67, 87-91. http://www.uaiasi.ro/zootehnie/Pdf/Pdf_Vol_67/Tas lim_Dawan.pdf

Dawan, T., \& Darana, S. (2018). Channel patterns and margin marketing analysis of slaughter drakes. Lucrări Știinţifice-Universitatea de Ştiințe Agricole și Medicină Veterinară, Seria Zootehnie, 69, 100-106. http://www.uaiasi.ro/zootehnie/Pdf/Pdf_Vol_69/Tas lim_Dawan.pdf

DGLAHS. (2020). Livestock and Animal Health Statistics 2020. Directorate General of Livestock and Animal Health Services. Ministry of Agriculture, Jakarta, Indonesia. https://ditjenpkh.pertanian.go.id/userfiles/download/ f18748813ab4f89601dedf7d3ee84e12.pdf

Dolan, C., \& Humphrey, J. (2000). Governance and trade in fresh vegetables: the impact of UK supermarkets on the African horticulture industry. Journal of development studies, 37(2), 147-176. https://doi.org/10.1080/713600072 
Drăgan, I. M., \& Isaic-Maniu, A. (2012). Snowball sampling developments used in marketing research. International Journal of Arts and Commerce, 1(6), 214-223.

https://ijac.org.uk/images/frontImages/gallery/Vol._ 1_No._6_/23.pdf

Fałkowski, J., Malak-Rawlikowska, A., \& MilczarekAndrzejewska, D. (2017). Farmers' self-reported bargaining power and price heterogeneity: Evidence from the dairy supply chain. British Food Journal, 119(8), 1672-1686. https://doi.org/10.1108/BFJ-112016-0570

Fugate, B., Sahin, F., \& Mentzer, J. T. (2006). Supply chain management coordination mechanisms. Journal of Business Logistics, 27(2), 129-161. https://doi.org/10.1002/j.2158-1592.2006.tb00220.x

Giuliani, E., Pietrobelli, C., \& Rabellotti, R. (2005). Upgrading in global value chains: lessons from Latin American clusters. World Development, 33(4), 549-573. https://doi.org/10.1016/j.worlddev.2005.01.002

Hayami, Y., Kawagoe, T., Marooka, Y., \& Siregar, M. (1987). Agricultural Marketing and Processing in Upland Java, A Prospective from Sunda Village. Bogor: CGPRT https://www.academia.edu/35406161/Agricultural_ Marketing_and_Processing_in_Upland_Java_A_Per spective_From_A_Sunda_Village

Janvier-James, A. M. (2012). A new introduction to supply chains and supply chain management: Definitions and theories perspective. International Business Research, 5(1), 194-207. https://doi.org/10.5539/ibr.v5n1p194

Kaplinsky, R. (2000). Globalisation and unequalisation: What can be learned from value chain analysis? Journal of Development Studies, 37(2), 117-146. https://doi.org/10.1080/713600071

Khaleda, S. (2013). The poultry value chain and sustainable development of poultry microenterprises that utilize homestead lands: A case study in Gazipur, Bangladesh. Land use Policy, 30(1), 642-651. https://doi.org/10.1016/j.landusepol.2012.05.010

Lambert, D. M., Stock, J. R., \& Ellram, L. M. (1998). Fundamentals of logistics management. http://repo.unikadelasalle.ac.id/index.php?p=show_ detail\&id=1294\&keywords=

Li, X., Zhao, S., \& Duan, X. (2020, December). Research on the Application of Computer Database Technology in Marketing. In 2020 5th International Conference on Mechanical, Control and Computer Engineering (ICMCCE) (pp. 1165-1168). IEEE. https://doi.org/10.1109/ICMCCE51767.2020.00256

Magdelaine, P., Spiess, M. P., \& Valceschini, E. (2008). Poultry meat consumption trends in Europe. World's Poultry Science Journal, 64(1), 53-64. https://doi.org/10.1017/S0043933907001717
Manning, L., \& Baines, R. N. (2004). Globalisation: a study of the poultry-meat supply chain. British Food Journal. https://doi.org/10.1108/00070700410561414

Manning, L., Baines, R., \& Chadd, S. (2008). Benchmarking the poultry meat supply chain. Benchmarking: An International Journal. https://doi.org/10.1108/14635770810864866

Marimin, M. N. (2010). Aplikasi Teknik Pengambilan Keputusan dalam Manajemen Rantai Pasok. Bogor: IPB

Press. https://books.google.co.id/books/about/Aplikasi_tek nik_pengambilan_keputusan_da.html?id=0 mf5DwA AQBAJ\&redir_esc $=y$

Mcleod, A., Thieme, O., \& Mack, S. D. (2009). Structural changes in the poultry sector: will there be smallholder poultry development in 2030?. World's Poultry Science Journal, 65(2), 191-200. https://www.tandfonline.com/doi/abs/10.1017/S004 3933909000129

Pica-Ciamarra, U. (2005). Livestock policies for poverty alleviation: Theory and practical evidence from Africa, Asia and Latin America (No. 855-2016-56211). https://ageconsearch.umn.edu/record/23772/

Pietrobelli, C., \& Saliola, F. (2008). Power relationships along the value chain: multinational firms, global buyers and performance of local suppliers. Cambridge Journal of Economics, 32(6), 947-962. https://doi.org/10.1093/cje/ben016

Qashiratuttarafi, Q., Adhi, A. K., \& Priatna, W. B. (2018). Analisis Nilai Tambah Pelaku Rantai Pasok Organisasi Jaringan Madu Hutan Sumbawa (Jmhs) Menggunakan Metode Hayami. Jurnal Agribisnis Indonesia (Journal of Indonesian Agribusiness), 6(2), 133-142. https://doi.org/10.29244/jai.2018.6.2.133-148

Schmitz, H., \& Knorringa, P. (2000). Learning from global buyers. Journal of Development Studies, 37(2), 177-205. https://doi.org/10.1080/713600073

Sihombing, D. T., \& Sumarauw, J. (2015). Analisis Nilai Tambah Rantai Pasokan Beras Di Desa Tatengesan Kecamatan Pusomaen Kabupaten Minahasa Tenggara. Jurnal EMBA: Jurnal Riset Ekonomi, Manajemen, Bisnis dan Akuntansi, 3(2). https://ejournal.unsrat.ac.id/index.php/emba/articl e/view/8902

Singh, D. \& Verma, A. (2018). Inventory management in supply chain. Materials Today: Proceedings, 5(2), 3867-3872.

https://doi.org/10.1016/j.matpr.2017.11.641

Susanti, R., Widiyastuti, K., Yuniastuti, A., \& Fibriana, F. (2020). Feed and Water Management May Influence the Heavy Metal Contamination in Domestic Ducks from Central Java, Indonesia. Water, Air, \& Soil Pollution, 231(4), 1-11. https://doi.org/10.1007/s11270-020-04559-1 
Nanang Febrianto et al. / American Journal of Animal and Veterinary Sciences 2021, 16 (3): 112.120 DOI: 10.3844/ajavsp.2021.112.120

Yu, X., \& Li, C. (2012). Research on supply chain of livestock products mode based on third-party logistics. In Proceedings of 2011 International Conference on Engineering and Information Management. http://www.ipedr.com/vol49/001A0005RE0312.pdf 